\title{
Brandeis and the Progressive Constitution: Erie, the Judicial Power, and the Politics of the Federal Courts in Twentieth-Century America
}

Edward A. Purcell, Jr.

New York Law School

Follow this and additional works at: http://digitalcommons.nyls.edu/fac_books

\section{Recommended Citation}

Purcell, Jr., Edward A., "Brandeis and the Progressive Constitution: Erie, the Judicial Power, and the Politics of the Federal Courts in Twentieth-Century America" (2000). Books. Book 25.

http://digitalcommons.nyls.edu/fac_books/25 


\section{Brandeis and the Progressive Constitution:}

\section{Erie, the Judicial Power, and the Politics of the Federal Courts in Twentieth-Century America}

EDWARD A. PURCELL, JR. 
For Rachel 


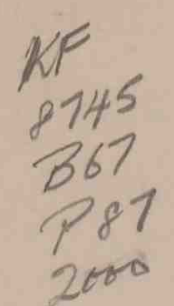

c. 3

Copyright @ 2000 by Yale University.

All rights reserved.

This book may not be reproduced, in whole or in part, including illustrations, in any form (beyond that copying permitted by Sections 107 and 108 of the U.S. Copyright Law and except by reviewers for the public press), without written permission from the publishers.

Designed by Gregg Chase.

Set in Monotype Fournier type by Tseng Information Systems.

Durham, North Carolina.

Printed in the United States of America.

\section{Library of Congress Cataloging-in-Publication Data}

Purcell, Edward A.

Brandeis and the progressive constitution : Erie, the judicial power, and the politics of the federal courts in twentieth-century America / Edward A. Purcell, Jr.

p. $\quad \mathrm{cm}$.

Includes bibliographical references and index.

ISBN 0-300-07804-8 (cloth : alk. paper)

1. Brandeis, Louis Dembitz, $1856-1941$. 2. Judges-United

States-Biography. 3. Law and politics. 4. Progressivism (United States politics) I. Title.

KF8745.B67P8 42000

$347.73^{\prime} 2634-D C 21$

A catalogue record for this book is available from the British Library.

The paper in this book meets the guidelines for permanence and durability of the Committee on Production Guidelines for Book Longevity of the Council on Library Resources.

10 98765432 


\section{Contents}

Acknowledgments

Introduction

PART I:

The Federal Judicial Power and Progressive Reform

I The Premise of an Age: Law, Politics, and the Federal Courts, I877-I937

2 Expanding the Federal Judicial Power: Justice David J. Brewer and the "General" Common Law

3 Progressive Judicial Reform After World War I: Diversity Jurisdiction and the Labor Injunction

PART II:

Brandeis, Erie, and the Complexities of Constitutional Judging

4 Litigant Strategies and Judicial Dynamics

5 Brandeis: The Judge as Human

6 "Defects, Social": The Progressive as Judicial Craftsman

7 "Defects, Political": The Progressive as Constitutional Architect 
PART III:

History and the Dynamics of Legal Change

8 Erosion and Creation of Meaning in an Age of Transition

9 Henry M. Hart, Jr., and the Power of Transforming Vision

Io Cold War Politics and Neutral Principles: The Federal Judicial Power 258 in a New Age

II To Century's End: Meaning, Politics, and the Constitutional Enterprise

Notes

Index 


\section{Acknowledgments}

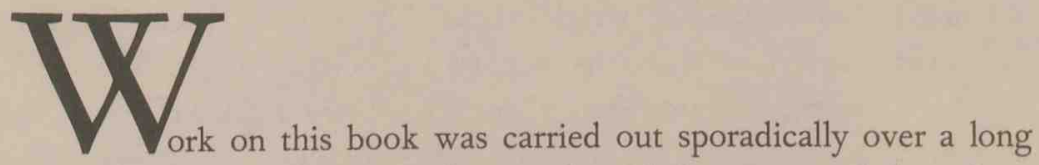

period of time, and I was able to complete it only with the generous help and encouragement of friends and colleagues and the support of a number of schools and institutions. Finishing the book gives me the gratifying opportunity to express my deep appreciation to them all.

For their illuminating scholarly assistance I thank my colleagues at New York Law School and the members of the legal history colloquium at New York University Law School who read and commented on early drafts. In addition, I owe a special debt of gratitude to a number of individuals who gave their time with special generosity and provided particularly helpful comments: Richard B. Bernstein, Robert Blecker, Mary Ann Case, Erwin Chemerinsky, Barry Cushman, Lawrence Fleisher, Helen Garfield, Dan Hamilton, Morton J. Horwitz, Alfred S. Konefsky, William P. LaPiana, David W. Levy, Scott L. Matthews, Eben Moglen, William E. Nelșon, Steven Newman, Rudolph J. R. Peritz, John Henry Schlegel, Peter H. Schuck, Richard Sherwin, James F. Simon, Henry Steiner, William M. Wiecek, Harry H. Wellington, and Donald H. Zeigler. Finally, I acknowledge the late Clifford S. Griffin for his encouragement and inspiration.

For their financial and administrative support I express my appreciation to the American Philosophical Society, the Social Science Research Council, the National Endowment for the Humanities, the American Council of Learned Societies, Harvard Law School, the University of Missouri-Columbia, New York University School of Law, and the law firm of Paul, Weiss, Rifkind, Wharton \& Garrison.

More recently, New York Law School has been generous in providing research assistance and in arranging my schedule to maximize the time available 
for writing. Dean Harry H. Wellington and Associate Dean Ellen Ryerson have been particularly supportive and encouraging. Professor Joyce Saltalamacchia, the director of the school's library, and her entire staff, especially Joseph Molinari and Michael McCarthy, have faithfully and happily supplied me with an unending flow of research materials. My research assistants, Elenor Reid, Anthony G. Di Maria, and Jennifer C. Argabright helped immensely in reviewing the manuscript and preparing it for publication, and my secretaries, Nicole Fischer, Billy Coleman, and Rosetta Reid, provided assistance in every way possible.

I also thank the following libraries for permission to cite and quote from material in their manuscript collections: Bancroft Library, University of California - Berkeley (Papers of Hiram W. Johnson and J. F. T. O'Connor); Library of Congress, manuscript division (Papers of Newton D. Baker, Hugo L. Black, Felix Frankfurter, Charles Evans Hughes, La Follette Family, James M. Landis, George W. Norris, Richard Olney, Donald Richberg, Harlan F. Stone, Willis Van Devanter, Thomas J. Walsh); Harvard Law School Library (Papers of Louis D. Brandeis, Felix Frankfurter, Learned Hand, Henry M. Hart, Jr., Oliver Wendell Holmes, Jr., and Roscoe Pound); Herbert Hoover Presidential Library (Papers of Herbert Hoover); Herbert Hoover Institution Archives, Stanford University (Papers of James Henry MacLafferty); Law Library, William Mitchell College of Law (Papers of William D. Mitchell and family); Franklin D. Roosevelt Presidential Library (Papers of Franklin D. Roosevelt); University of Virginia Law Library Special Collections (Papers of James C. McReynolds); Southern Historical Collection, Wilson Library, University of North Carolina - Chapel Hill (Papers of John J. Parker).

Similarly, Yale University Press provided a particularly supportive and helpful editorial process. I thank Clyde Spillenger for a particularly thorough and helpful review, and John Covell and Nancy Moore Brochin for their insightful comments and their careful reading and thorough editing of the manuscript.

My greatest thanks goes to my family. My wife, Rachel Vorspan, my son Dan, and my daughter Jess have filled my life with joy, and their companionship and support have encouraged my work and eased its burdens. My in-laws, Max and Sandy Vorspan, were unfailingly hospitable and supportive during my working visits to California. Finally, Professor Rachel Vorspan contributed her insights as both lawyer and historian, helping immeasurably to focus and strengthen the book. 
Brandeis and the Progressive Constitution 


\section{Introduction}

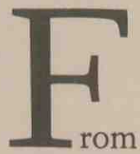

rom the moment that Justice Louis D. Brandeis announced the Supreme Court's decision in the spring of 1938 , Erie Railroad Co. $v$. Tompkins has fascinated members of the legal profession. ${ }^{1}$ Reaching far beyond Harry Tompkins's personal injury claim, Brandeis's decision addressed fundamental constitutional issues involving the locus and scope of lawmaking authority in the American legal system. Overruling Swift $v$. Tyson, a ninety-six-year-old decision that had expanded the power of the national courts to create a "general" federal common law independent of the common law of the states, it sought to limit that judicial power and rebalance the lawmaking structure of American government.

As massive historical changes altered the social and political significance of Swift, however, they did the same to Brandeis's creation. To view Erie through the historian's eyes - to consider its complex social origins, its purposeful human crafting, and its shifting but nevertheless patterned reinterpretation over the years - is to explore both the sweep of American experience in the twentieth century and the practices of its legal and political elites in molding the nation's rules, concepts, principles, and ideologies of law. The changing national experience and the evolving ideas and legal practices are examined here, as much as or more than Brandeis and his decision. This book is a work of history, not of law. ${ }^{2}$

In Part I, Chapters I through 3 provide an overview of the period from 1877 to 1937 , highlighting a range of developments that helped create the distinct politico-constitutional age that shaped Brandeis's views and ultimately gave birth to Erie. This period was marked by a fundamental premise concerning the role of the federal courts and the relationship between the legislative and judicial branches. Legal commentators of all stripes came to see the judiciaryespecially the federal judiciary - as the branch of government that would most consistently protect private property and interstate corporate enterprise. They 
viewed state and federal legislatures - and sometimes even state courts - as the branches most likely to threaten those interests. In the decades surrounding the turn of the century the Supreme Court expanded the reach of federal judicial power to increase the ability of the federal courts to review government regulatory efforts, while Progressives* came to believe that significant social and economic reform could take place only if that power were limited and state and national legislative powers were expanded. These developments, this book argues, underlay Brandeis's constitutional theory.

Part 2 focuses on Brandeis - his judicial practice, his evolving constitutional philosophy, and his opinion in Erie for a bare five-justice majority. Chapters 4 through 7 argue that Brandeis played the preeminent role both in forging a majority and in shaping the Court's final opinion, and they provide insight into the meaning of Brandeis's decision by relating it to his values, politics, personal motivations, and overall constitutional jurisprudence. These chapters conclude that Brandeis was animated by broad personal and social purposes and that he sought to use his opinion to institutionalize the goals and values of earlytwentieth-century Progressivism.

Part 3 considers the fate of Brandeis's decision and his Progressive ideals in a new and different postwar world. Chapters 8 through to argue that tumultuous historical changes ripped his opinion from its cultural moorings and propelled it into a drastically different world where judges and legal scholars viewed it with new eyes. These chapters explore the subsequent interpretations that fundamentally reshaped Brandeis's opinion as later generations struggled to control the scope and function of the federal judicial power in a new politicoconstitutional age.

Chapter II, the final chapter, sketches developments of the past quarter century. Writing "recent" history (where the conscious and unconscious promptings of contemporary concerns are powerful) is difficult, especially when the subject is law. Erie remains deeply embedded in continuing professional disputes, and its history bears an immediate normative significance that other historical subjects often lack. The scholarly commentary, moreover, has reached staggering proportions. To treat that literature with justice would require a separate book, and to identify its most significant and enduring contributions would require a perspective that is as yet unavailable. Thus, the final chapter brings the story of Brandeis and Erie to century's end by noting its highlights.

\footnotetext{
*The word Progressive is capitalized to refer to the ideas, values, and assumptions that characterized many of the reform movements of the early twentieth century, particularly their widely shared if somewhat varied commitments to science, expertise, efficiency, popular education, democratic government, the rights of labor, the limitation of corporate power, and the use of government to ameliorate the harsh consequences of industrialization. The term does not refer to the formal Progressive party that was organized around Theodore Roosevelt.
} 
Through its three parts, the book explores the complex relationship between changing American politics and evolving ideas concerning the practice of constitutional government and the role of the federal judiciary. On one level, it examines the origins and intended significance of the Court's landmark decision in Erie. Recognizing the complexities and ambiguities of the issues involved, it nevertheless concludes that the case has been widely misunderstood, in large part because judges and legal scholars have too often divorced it from its full and vital historical context. It was neither a simple articulation of the positivism of Justice Oliver Wendell Holmes, Jr., nor the inevitable result of a "philosophical revolution" in the Court's understanding of "law." The book suggests that commentators have persistently overemphasized Erie's "philosophical" content while minimizing or ignoring other more important elements. Similarly, the decision was not designed primarily to protect "federalism" or special enclaves of state law. Rather, its more vital concern lay in broader ideas about judicial lawmaking and separation of powers. Nor, again, was Erie simply a product of the "constitutional revolution" that the Supreme Court carried out after spring 1937. It was closely related to that pivotal period, but it bore an oblique and problematic relationship to the jurisprudence of the "Roosevelt Court."

On a second level, the book is a study of Brandeis and his work as a constitutional judge. It explores the tensions that arose from his political Progressivism, his role as a justice, his strategic position on a historically specific Court, and his developing and purposeful constitutional jurisprudence. The book posits that Erie reflected Brandeis's deepest concerns and illuminated central elements of his judicial practice and philosophy. More particularly, it argues that his purpose in Erie was not only to destroy the doctrine of Swift $v$. Tyson, reject its ostensibly outmoded jurisprudence, and terminate its generally pro-corporate consequences. Instead, his broader goal.was twofold. First, Brandeis sought to restructure the American judicial system to increase both its operational efficiency and its capacity to provide practical justice. Erie was an integral part of his longterm effort to adapt the court system of the states and the nation to the demands of a new interstate society. Second, Brandeis sought to constrain a pervasive if amorphous judicial practice by which the Supreme Court had, for more than half a century, used common law techniques to expand its lawmaking powers and, all too often, to serve anti-Progressive purposes. Brandeis wrote Erie not only to terminate the "federal general common law" but also to cabin more generally the lawmaking powers of the national courts in a variety of cognate areas.

On a third level, the book uses Erie as a case study to explore the ways in which historical processes shape and reshape fundamental ideas about legal doctrines, the role of the judiciary, and the nature of constitutional government. The world of early twentieth-century Progressivism inspired both Brandeis and his 
decision in Erie, but that world was expiring as Brandeis drafted and delivered his opinion. His reasoning and purposes could hardly have maintained their full intended meaning in a radically new age. The book shows how succeeding generations of judges and scholars worked, sometimes consciously and sometimes not, to remake both Brandeis's image as a constitutional judge and his opinion in Erie. The decision was not the "founding document of modern American judicial federalism," as one distinguished scholar has termed it, nor was it the case that "shaped the agenda and analysis of the legal process school" that grew to prominence in the postwar decades, as another equally distinguished commentator has declared. ${ }^{3}$ True, it was subsequently tailored to those purposes, but Brandeis's intent was quite different. Indeed, Erie was quite different from the polestar version that Professor Henry M. Hart, Jr. - the decision's most brilliant and influential scholarly advocate - imagined and confidently proclaimed to the world.

Brandeis's decision, the book argues further, was also quite different from the famous precedent that the United States Supreme Court repeatedly applied during the succeeding half century. It was not the case Justice Felix Frankfurter explained so carefully in Guaranty Trust Co.v. York, nor the decision Chief Justice Earl Warren implemented in Hanna v. Plumer, nor the opinion Justice Lewis F. Powell, Jr., invoked so forcefully in Cannon v. University of Chicago. ${ }^{4}$ Because of the Court's immense power and prestige - and because its pronouncements constitute "authoritative" statements of "the law" - its interpretations over the years tend to blur, obscure, and then replace broad and complex historical understandings with formalized doctrines. That elaborate formal practice of redefining and remaking legal rules is an essential part of the legal process. As a matter of historical understanding, however, it is dysfunctional. Equally important, as a matter of legal doctrine, the practice is also a powerful force for covert change. In both its origins and subsequent interpretation, the history of Erie $v$. Tompkins illuminates the way individual perspectives and social pressures have driven the law's contingent evolution. In this critical sense, the book explores Erie, an unusual case in so many respects, as representative.

As the book explores the complex dynamics of legal change, it suggests a number of conclusions. It points, for example, to the historicity of that most exalted, rigorous, and frustrating law school course (labeled differently from school to school), "Federal Courts." Inspired by the confrontation between progressivism, professionalism, and the conservative politics of the 1920s, this now standard course and respected field of study was largely inspired by Brandeis and molded by Frankfurter in the process of grappling with the legal parameters of pressing social and political conflicts. Born of political commitment and ideological conviction, the idea of "Federal Courts" as a special field of scholarly study spread in the I930s and I940s and then grew to maturity following 
World War II. Historical changes between the Great Depression and the cold war, however, altered the field of study, fragmented its assumptions, and confused its purposes. Thus, the field changed substantially in the decades following World War II, with few students recognizing the exact nature of those changes. Indeed, only recently have "Federal Courts" scholars even begun to consider the extent to which their subject is the confected product of distinctive historical developments.

The book shows, too, that aspects of the grand historical synthesis that Frankfurter designed over the course of his life as scholar and judge were highly misleading. In particular, it highlights significant issues that divided Brandeis and Frankfurter after the mid-I930s and emphasizes Frankfurter's changing views, his role in remolding Erie's significance for his own purposes, and his subsequent efforts to recast Brandeis's judicial image to provide support in his constitutional battles with Justice Hugo L. Black and the early Warren Court. It also explores the differences that developed between Frankfurter and Hart, his brilliant student and colleague, over the nature of the federal judicial system and the constitutional role of the national courts. During the period of Hart's greatest intellectual achievements, from World War II into the 1960s, he was far more a judicial activist and nationalist (and had a far more ambiguous relationship to both Frankfurter and the Warren Court) than has been commonly acknowledged.

More generally, the book points to the critical role "branch affinities" played in the ideological commitments of diverse political partisans to the different branches of government. It suggests that such foundational ideas as federalism, separation of powers, and the respective constitutional roles of the various branches of government are rooted largely in expectations concerning the practical consequences that varying allocations of institutional authority would likely cause. The legal meaning and political significance of those foundational ideas shift, fragment, and realign over time as controlling social and political expectations are transformed.

Finally, in the process of probing for a "historical Erie,"the book raises deep, if familiar, doubts about the concept of a knowable and authoritative "original intent." ${ }^{5}$ To provide insight into Brandeis's purposes and strategies, the book addresses a single decision, on a clearly defined issue, well known and widely discussed both prior to and contemporaneously with the decision, and made by a group composed of a mere five individuals who acted only sixty years ago and who bequeathed to us a relatively extensive and informative documentary record. Indeed, arguing that Brandeis was Erie's dominant author, the book focuses largely on a single individual who left behind an extraordinarily rich and voluminous collection of relevant materials, including especially valuable 
and revealing private letters and working judicial papers. Despite these quite exceptional advantages, however, the inquiry relies unavoidably on the historian's inference and speculation. Thus, answers to even relatively simple, recent, and specific questions - even when based on unusually abundant and illuminating sources - remain tentative and incomplete.

The analysis, moreover, highlights problems and ambiguities that plague efforts to use "original intent" as an authoritative legal norm. It argues, for example, that Brandeis's reasoning in Erie was flawed because he had to navigate around the views of the four justices who joined him to create his bare majority. At least two, and possibly all four, of them apparently misunderstood, doubted, or disagreed with the constitutional language Brandeis chose. The opinion was also flawed because Brandeis made conscious tactical decisions to obscure and avoid as well as to illuminate and effectuate. ${ }^{6}$ Thus, the Court's opinion was, in places, opaque and misleading by design. The analysis, in short, supports those who argue that the idea of a normative "original intent" makes historical inquiry the oracle of answers that it often cannot provide. Equally important, the analysis also suggests that a fully "authentic" original intent-even if discoverable and applicable to the questions that later generations pose - may not be persuasive, serviceable, or even recognizable to those later generations who ask new questions on the basis of their new and different perceptions and assumptions.

Seriously qualifying and limiting (although hardly rejecting) ideas of original intent, the book suggests that historical evolution creates limitations and imperatives that infuse with new meaning the words of authoritative documents. The test of the wisdom and validity of those new meanings is only partially a historical question. We can learn far more by recognizing and understanding that continuous process of change and reinterpretation than by pretending that we can discover and apply an objective and legally directive "original intent" free from the limitations, pressures, and needs of our time.

Although the book questions both the utility and validity of most purportedly normative and directive ideas of original intent, it shows that histori$\mathrm{cal}$ analysis carries distinctive virtues. Historical analysis can clarify the ways in which changing values, problems, and circumstances drove the evolution of constitutional assumptions and practices; it can aid us in understanding how past generations strove to make complex socio-legal processes work; and it can illuminate the ways in which the various institutions and rules of law affected the diverse elements of American society. Historical analysis need not boast complete truth or promise authoritative answers to specific legal questions in order to help us - and future generations - learn how we might continue to shape those processes to sustain and enhance a decent, ordered, and relatively democratic life.?

Accordingly, the book hazards a broader historical, constitutional, and 
normative conclusion. It suggests that Brandeis and his opinion in Erie, although flawed, were admirable. This conclusion is based on a complex judgment that in his opinion, as in his judicial career, Brandeis successfully combined four paramount virtues: he articulated sound and fundamental constitutional principles; he served the cause of popular, representative government; he adapted legal rules effectively to serve desirable institutional goals; and he improved the ability of the legal system to provide practical justice to the weak and disadvantaged. 